\title{
Fulminant Myocarditis in Covid 19 - Case report
}

\author{
Elena Grueva Nastevska ${ }^{1}$, Irina Kotlar ${ }^{1}$, Elma Kandic $^{1}$, Vladislav Gruev ${ }^{2}$, \\ Ana Chelikikj ${ }^{1}$, Emilija Lazarova ${ }^{1}$, Irena Mitevska ${ }^{1}$, Oliver Busljetic ${ }^{1}$ \\ ${ }^{1}$ University clinic of Cardiology, Majka Tereza 17, \\ 1000 Skopje, Republic of North Macedonia \\ ${ }^{2}$ University clinic "St. Naum Ohridski", 11 Oktomvri 53, \\ 1000 Skopje, Republic of North Macedonia
}

Received: November 2021; Accepted: November 2021

\begin{abstract}
Fulminant myocarditis (FM) is a syndrome characterized by sudden and severe diffuse cardiac inflammation often leading to death resulting from cardiogenic shock, ventricular arrhythmias, or multi-organ system failure. Clinical presentations vary widely, but the main characteristic is a rapidly progressive clinical course with the need of hemodynamic support. We present a clinical case of a patient with COVID-19 admitted to our cardiac intensive care unit with severely reduced left ventricular ejection fraction and worsening clinical course ending in cardiogenic shock in a very short time. The only available imaging technique in these fast-deteriorating patients is the bedside echocardiography, helping to provide accurate assessment and adequate treatment as soon as possible. Even though the current recommendations imply the use of cardiac magnetic resonance (CMR) and endomyocardial biopsy (EMB) as a diagnostic tool for myocarditis, their application in the COVID-19 pandemic is limited. The use of inotropes and mechanical support is the recommended and the final challenge as a bridge to recovery or bridge to transplant. In the settings where CMR and EMB are not feasible from an infection control standpoint, the diagnose should rely on the integration of clinical, laboratory (cardiac biomarkers), electrocardiographic (ST-segment changes), and echocardiographic -wall motion abnormalities, ejection fraction, and pericardial effusion- data.
\end{abstract}

Keywords: myocarditis; COVID-19; cardiogenic shock; echocardiography; endomyocardial biopsy

\section{Introduction}

The true prevalence of COVID-19 acute myocarditis is unknown. Several cases of clinically diagnosed myocarditis in patients with COVID-19 have been reported, but the number of autopsy and endomyocardial biopsy (EMB) proven cases is still limited.

Myocarditis is classified as acute, chronic or fulminant, the latter being a sudden, severe manifestation associated with acute heart failure, cardiogenic shock and life-threatening arrhythmias. Viral infections such as enteroviruses and adenoviruses are common causes of myocarditis, which can cause a combination of direct cellular injury and T-cell cytotoxic response (Caforio et al., 2013).

Outcome and prognosis of myocarditis depends on aetiology, clinical presentation, and disease stage. Acute myocarditis resolves in about $50 \%$ of cases in the first 2 4 weeks, but about $25 \%$ will develop persistent cardiac dysfunction and 12-25\% may acutely deteriorate and either die or progress to end-stage dilated cardiomyopathy (DCM) with a need for heart transplantation (Ranard et al., 2020).

\footnotetext{
*gruevaelena@gmail.com
} 


\section{Case report}

73 years old male, with history of diabetes and hypertension, was admitted in our cardiac intensive care unit, transferred from the Clinic of endocrinology where he was treated due to hyperosmolar hyperglycemic state. On admission the patient's cardiovascular examination revealed him to be tachyarrhythmic without audible heart murmurs or an elevated jugular venous pressure. The respiratory examination revealed soft inspiratory crackles bibassaly. His vital signs included a heart rate of 149 b.p.m., blood pressure of 119/63 mmHG, pulse oximetry of $86 \% \mathrm{SaO}_{2}$ and a body temperature of $37.9{ }^{\circ} \mathrm{C}$. The initial chest X-ray showed no abnormalities of the lung parenchyma. The biomarkers of myocardial injury were significantly elevated (cTn $-40.103 \mathrm{ng} / \mathrm{L}$ ) along with the levels of blood creatinine and urea. Electrocardiography (ECG) showed atrial fibrillation with non-specific ST segment and $\mathrm{T}$ wave changes (Fig. 1).

Bedside echocardiography was made immediately, and the findings were: mildly enlarged left ventricle with severely reduced ejection fraction (26\%), with a global hypokinesia and global longitudinal strain of $-6.0 \%$. Right ventricle with normal size and a formation suspected for thrombus in the right atrium (Fig. 2).

Shortly after the admission, his clinical course deteriorated, and he was in cardiogenic shock. Inotropic treatment was initiated with norepinephrine $8 \mathrm{~mL} / \mathrm{h}$ and dobutamine $10 \mathrm{mcg} / \mathrm{kg}$ along with anticoagulation low molecular weight heparin (LMWH) in therapeutic doses of $1 \mathrm{mg} / \mathrm{kg} / 12 \mathrm{~h}$, intravenous furosemide for decongestion $60 \mathrm{mg} / 12 \mathrm{~h}$, antiarrhythmic treatment with amiodarone bolus doses and broad-spectrum $\beta$-lactam cephalosporin 2 $\mathrm{g} / 24 \mathrm{~h}$. The blood gas analysis showed elevated lactate $3.4 \mathrm{mmol} / \mathrm{L}$, hypo saturation and compensated metabolic acidosis. He was tested for SARS-COV2 and the test was positive. Unfortunately, due to the patient's rapidly progressive clinical course, cardiac magnetic resonance imaging wasn't feasible. The patient was hemodynamically stabilized, and under suspicion for fulminant myocarditis based on the ECG, laboratory and echocardiography findings, he was transferred to a cardiac covid intensive care unit. Two days later his condition got worse and the patient died.

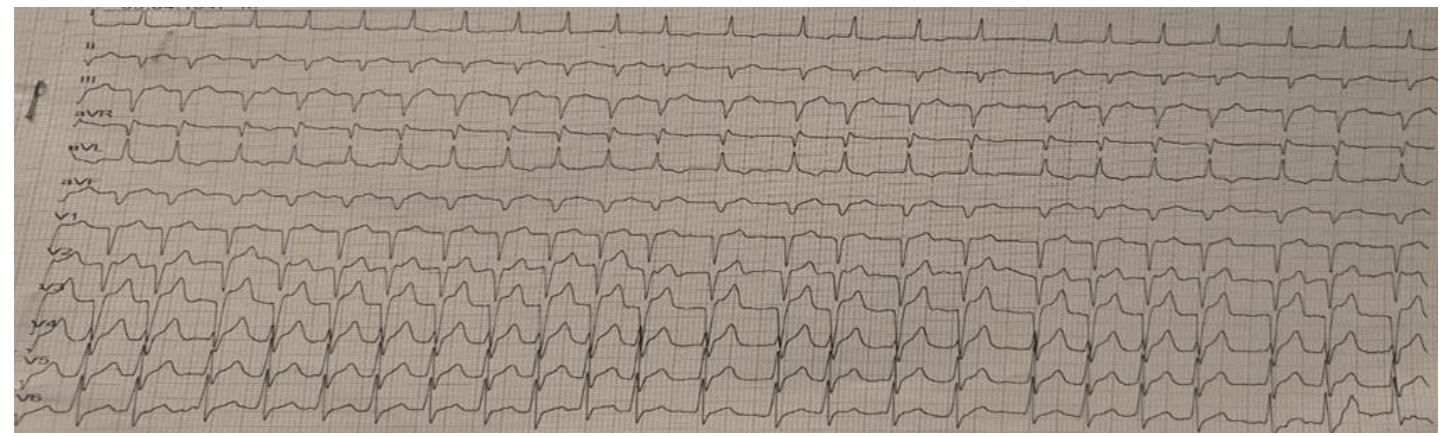

Fig. 1. ECG showing atrial fibrillation with heart rate of $\sim 150 / \mathrm{bpm}$.

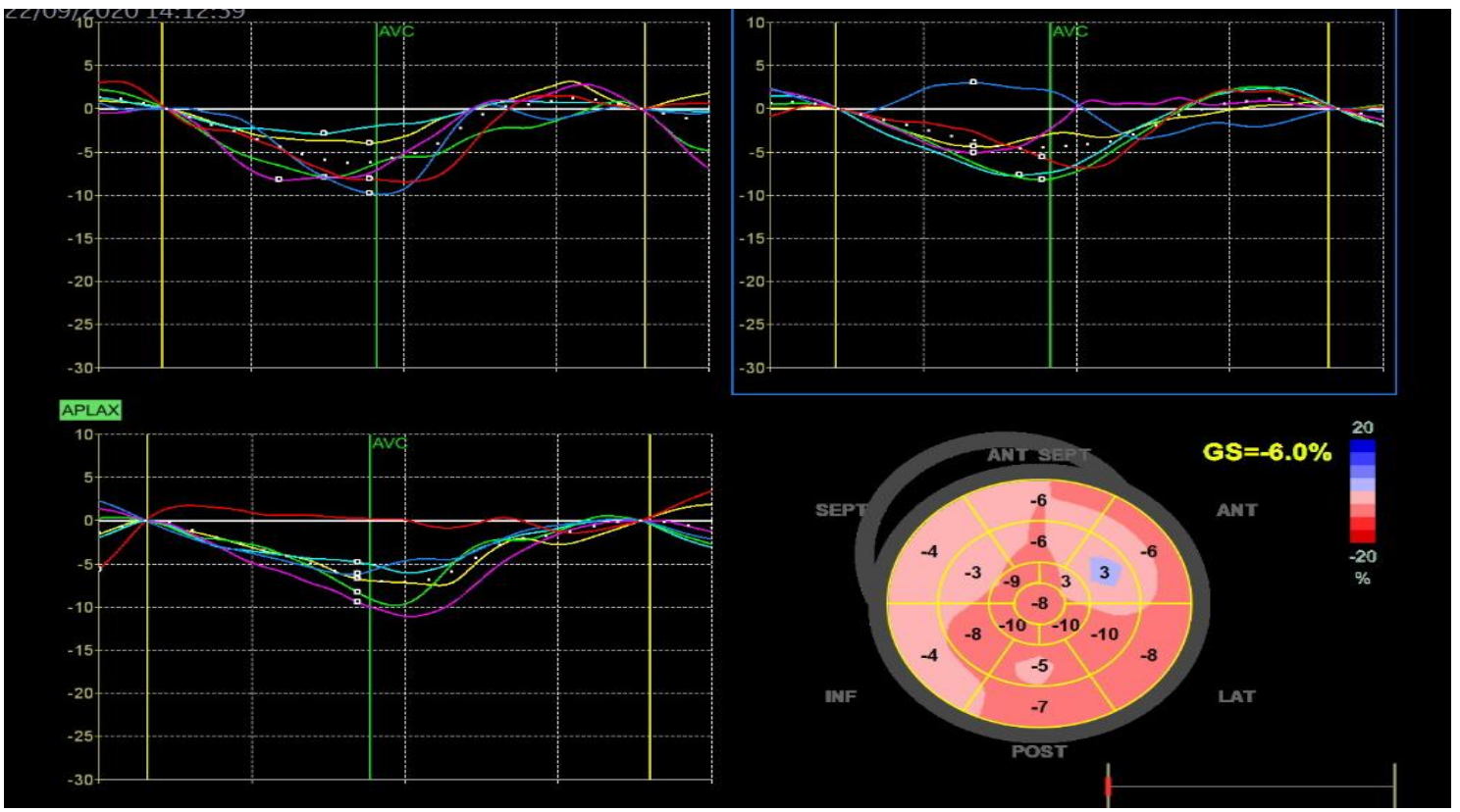

Fig. 2. Severely reduced global longitudinal strain of left ventricle. 
Table 1. Indication and recommendation for endomyocardial biopsy

\title{
(Class I indication)
}

Joint statement from the American Heart Association

(AHA), American College of Cardiology, and European Society of Cardiology (ESC) in 2007
1. Unexplained, new-onset heart failure of $<2$ weeks' duration that is associated with hemodynamic compromise;

2. In the setting of unexplained new-onset heart failure between 2 weeks' and 3 months' duration that is associated with a dilated LV and new bradyarrhythmia (Mobitz II or complete heart block), new ventricular arrhythmias, or a failure to respond to standard care within 1 to 2 weeks of diagnosis.

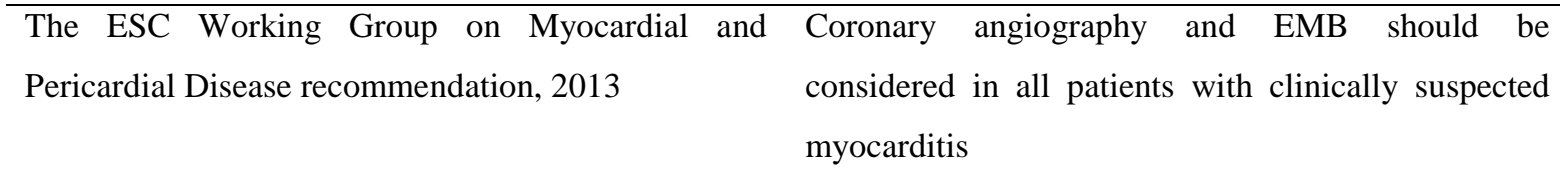

AHA scientific statement, 2016

\begin{abstract}
EMB may be considered in heart failure that is rapidly progressing when there is a high suspicion that the cause can be confirmed only by myocardial histology
\end{abstract}

\section{Discussion}

Even though the current recommendations imply the use of cardiac magnetic resonance (CMR) and EMB as a diagnostic tool for myocarditis, their application in the COVID-19 pandemic is limited, as it was in our case (Jamie et al., 2020).

\section{Cardiac magnetic resonance}

Consensus guidelines (Lake Louise criteria) have recommended taking into account at least 2 of $3 \mathrm{CMR}$ tissue characterization criteria for myocarditis $(79 \%$ diagnostic accuracy):

(1) edema (as quantified by global or regional T2 enhancement)

(2) scar or active inflammation (by late gadolinium enhancement (LGE) imaging, usually in a regional or global subepicardial distribution, although subendocardial infarct LGE has been observed)

(3) evidence of myocardial hyperemia (by enhancement early after gadolinium).

\section{Endomyocardial biopsy}

In acute/fulminant cases with cardiogenic shock and severe ventricular dysfunction, ventricular assist devices or extracorporeal membrane oxygenation (ECMO) may be needed to provide a bridge to transplant or to recovery.

Unfortunately, their use is not a routine in our cardiac centers and their application is limited, even though it can be life-saving in these settings. In our everyday practice in the intensive care units, we are observing patient's status deteriorates in very short time, so the only applicable methods for diagnosis are the ones available "bedside".

Early use of echocardiography is essential to establish a diagnosis and the severity of cardiovascular compromise (Veronese et al., 2018).

In the settings where CMR and EMB are not feasible from an infection control standpoint, the diagnose should rely on the integration of clinical, laboratory (cardiac biomarkers), electrocardiographic (ST-segment changes), and echocardiographic -wall motion abnormalities, ejection fraction, and pericardial effusion- data. 
Heart failure and arrhythmias caused by myocarditis should be optimally managed, including use of diuretics, angiotensin converting enzyme inhibitors, beta-adrenergic blockers, anti-arrhythmic medication, anticoagulation therapy, temporary pacing and ECMO. Immunomodulatory therapy using anti-viral medications and intravenous immunoglobulins has been suggested but evidence of benefit is limited (Yen et al., 2019). Immunosuppression using steroids, azathioprine and ciclosporin is often attempted but guidelines recommend that they should be started only after ruling active infections by polymerase chain reaction.

\section{Conclusion}

The European Society of Cardiology (ESC) position statement on the management of acute myocarditis recommends the assessment of serum cTn, erythrocyte sedimentation rate, and $\mathrm{C}$-reactive protein to aid in the diagnosis of myocarditis. In the presented case report the early use of echocardiography was performed in order to establish a diagnosis and to estimate the severity of the cardiovascular compromise. Interesting finding in our case report is the sudden cardiac manifestation of the COVID19 without the usual clinical signs of respiratory tract involvement. As CMR and EMB where are not available from an infection control standpoint, the diagnose was obtained with integration of clinical, laboratory, electrocardiographic, and echocardiographic-wall motion abnormalities, ejection fraction, and pericardial effusiondata. Future studies should focus on reliable diagnosis of myocarditis in an outbreak scenario, and characterizing these patients in larger, prospective studies.

\section{References}

Caforio, A.L., Pankuweit, S., Arbustini, E., Basso, C., GimenoBlanes, J., Felix, S.B., Fu, M., Heliö, T., Heymans, S., Jahns, R., Klingel, K., Linhart, A., Maisch, B., McKenna, W., Mogensen, J., Pinto, Y.M., Ristic, A., Schultheiss, H.P., Seggewiss, H., Tavazzi, L., Thiene, G., Yilmaz, A., Charron, P., Elliott, P.M., European Society of Cardiology Working Group on Myocardial and Pericardial Diseases, 2013. Current state of knowledge on aetiology, diagnosis, management, and therapy of myocarditis: a position statement of the European Society of Cardiology Working Group on Myocardial and Pericardial Diseases. Eur. Heart J. 34(33), 2636-2648. Available at: https://doi.og/10.1093/eurheartj/eht210.

Ho, J.S., Sia, C.H., Chan, M.Y., Lin, W., Wong, R.C., 2020. Coronavirus-induced myocarditis: A meta-summary of cases. Heart Lung 49(6), 681-685. Available at: https://doi.org/10.1016/j.hrtlng.2020.08.013.

Ranard, L.S, Fried, J.A., Abdalla, M., Anstey, D.E., Givens, R.C., Kumaraiah, D., Kodali, S.K., Takeda, K., Karmpaliotis, D., Rabbani, L.E., Sayer, G., Kirtane, A.J., Leon, M.B., Schwartz, A., Uriel, N., Masoumi, A., 2020. Approach to Acute Cardiovascular Complications in COVID-19 Infection. Circ. Heart Fail. 13(7), e007220. Available at: https://doi.org/10.1161/CIRCHEARTFAILURE.120.0072 20.

Veronese, G., Ammirati, E., Cipriani M., Frigerio, M., 2018. Fulminant myocarditis: Characteristics, treatment, and outcomes. Anatol. J. Cardiol. 19(4), 279-286. Available at: https://doi.org/10.14744/AnatolJCardiol.2017.8170.

Yen, C.Y., Hung, M.C., Wong, Y.C., Chang, C.Y., Lai, C.C., Wu, K.G., 2019. Role of intravenous immunoglobulin therapy in the survival rate of pediatric patients with acute myocarditis: A systematic review and meta-analysis. Sci. Rep. 9, 10459.Available at: https://doi.org/10.1038/s41598-019-46888-0. 


\title{
Резиме
}

\section{Фулминантен миокардитис кај КОВИД-19 - Приказ на случај}

\author{
Елена Груева Настевска ${ }^{1}$, Ирина Котлар ${ }^{1}$, Елма Кандиќ ${ }^{1}$, Владислав Груев ${ }^{2}$, \\ Ана Челикиќ ${ }^{1}$, Емилија Лазарова1, Ирена Митевска ${ }^{1}$, Оливер Бушљетиќ ${ }^{1}$ \\ ${ }^{1}$ Универзитетска клиника за Кардиологија, Мајка Тереза 17, \\ 1000 Скопје, Република Северна Македонија \\ ${ }^{2}$ Универзитетска клиника „Св.Наум Охридски”, 11 Октомври 53, \\ 1000 Скопје, Република Северна Македонија
}

Клучни зборови: миокардитис, КОВИД-19, кардиоген шок, ехокардиографија, ендомиокардна биопсија

Фулминантниот миокардитис (ФМ) е синдром кој се карактеризира со тешка инфламација на срцевиот мускул која најчесто води до смрт која е резултат на кардиоген шок, вентрикуларни аритмии или мултиорганска слабост. Клиничката презентација може да варира пошироко, но главната карактеристика е брзиот прогресивен клинички тек кој најчесто завршува со потреба од хемодинамска поддршка. Во овој клинички случај, презентираме пациент со КОВИД-19 примен на нашата кардиолошка интензивна нега со изразено редуцирана левокоморна систолна функција и клинички тек со брзо влошување кое резултираше со кардиоген шок. Единствената сликовна техника, која може да даде прецизна дијагноза кај овие пациенти е ехокардиографијата во легло, која е лесно достапна и е најбрз начин да се спроведе соодветниот третман. Иако тековните водичи ја препорачуваат ендомиокардната биопсија (ЕМБ) и срцевата магнетна резонанца (СМР) како златен стандард за дијагноза на миокардитис, нивната употреба за време на КОВИД-19 пандемијата е ограничена. Кај овие пациенти, неретко е потребна хеммодинамска поддршка со инотропи и механичка циркулаторна поддршка. Во услови кога ЕМБ и СМР не се изводливи и поради клиничката состојба на пациентот и од аспект на потребата од контрола на инфекции, дијагнозата треба да се заснова врз интегрирани наоди кои вклучуваат клинички, лабораториски (срцеви биомаркери), електрокардиографски (промени во СТ сегментот), и ехокардиографски нарушувања (ежекциона фракција и перикарден излив). 
